\title{
Efek Metoda Aplikasi dan Dosis Pupuk Hayati Penambat N terhadap Serapan N, Pertumbuhan dan Hasil Tanaman Padi pada Tanah Salin
}

\author{
Toto Bustomi ${ }^{1}$, Betty Natalie Fitriatin ${ }^{2}$ dan Tualar Simarmata ${ }^{2}$ \\ ${ }^{1}$ Mahasiswa Program Studi Pascasarjana Ilmu Tanah Fakultas Pertanian Universitas Padjadjaran \\ ${ }^{2}$ Staff Pengajar Program Studi Agroteknologi Fakultas Pertanian Universitas Padjadjaran \\ Jl. Raya Bandung Sumedang Km 21, Jatinangor \\ Korespondensi: bustomi.toto@gmail.com
}

\begin{abstract}
Appropriate method and dosage of $N$-fixing biofertilizer are the keys to success in increasing $N$ uptake, growth and yield of rice plants on saline soils. Research objectives: to obtain the application method and dosage of $N$-fixing biological fertilizers which gave the best effect on bacterial populations, $N$ content, $N$ uptake, growth (plant height and number of tillers), yield components (number of panicles per clump, number of grains per panicle, percentage of grain. content, and weight of 1000 grains) and rice yields on saline soils. The research was conducted in June-September 2018 at the BPP Cilamaya Wetan Experimental Garden, using a factorial randomized block design with 3 replications. The first factor is the method of applying $\mathrm{N}$-fixing biofertilizers (300, 400, $700 \mathrm{~g}^{\mathrm{h}} \mathrm{ha}^{-1}$ ) and the second factor doses of $\mathrm{N}$-fixing fertilizer (500, $1000,1500 \mathrm{~g} . \mathrm{ha}^{-1}$ ). The results showed that the application of $1500 \mathrm{~g} \cdot \mathrm{ha}^{-1}$-fixing biological fertilizer had the best effect on bacterial populations, $N$ levels, $N$ uptake, plant height, number of tillers, number of panicles per clump, number of grains per panicle, percentage of filled grains, and 1000 grain weight, and increased rice yields on saline soil by $29.70 \%$.
\end{abstract}

Keywords: $N$-fixing biofertilizers, application method, dosage, rice, saline soil.

\section{PENDAHULUAN}

Padi sampai sekarang masih merupakan tanaman terpenting di Indonesia, karena permintaan beras sebagai bahan makanan pokok masih terus meningkat sejalan dengan pertumbuhan penduduk dan perkembangan ekonomi. Tahun 2017 konsumsi beras nasional mencapai 285 ton per tahun dengan tingkat konsumsi 111,58 kg per kapita per tahun (BPS, 2017). Upaya pemerintah untuk memenuhi kebutuhan beras nasional yaitu program Peningkatan Produksi Beras Nasional (P2BN) tahun 2007 dan Upsus Padi tahun 2016.

Program P2BN dan Upsus Padi pada prakteknya masih mengandalkan sawah irigasi di daerah sentra produksi padi yang sebagaian besar terletak di sekitar wilayah pantai. Perubahan iklim global saat ini, menyebabkan daerah sentra produksi padi di sepanjang pesisir pantai, terutama daerah pantai utara (PANTURA) Jawa Barat, terancam cekaman salinitas akibat sedikitnya pasokan air irigasi pada saat musim kemarau atau akhir musim hujan dan intrusi air laut (Erfandi dan Juarsah, 2013). Selain itu perluasan luas baku sawah berjalan sangat lambat hanya mampu menaikkan hasil panen kurang dari 1\% per tahun dan sebagian besar terjadi di luar Jawa yang memanfaatkan lahan sub optimal yang diantaranya bersifat salin (Wahyunto, 2009).

Nitrogen (N) berperan penting dan menjadi faktor pembatas dalam budidaya padi. Selama ini input $\mathrm{N}$ diperoleh dari pupuk anorganik yang bila diberikan terus-menerus dapat menurunkan kualitas tanah dan menurunkan efisiensi pupuk. Sedangkan sumber terbesar nitrogen $78 \%$ terdapat di udara dalam bentuk $\mathrm{N}_{2}$ yang hanya dapat dimanfaatkan oleh tanaman melalui bantuan bakteri penambat N (Widawati et. al., 2015).

Salah satu jenis bakteri yang dapat digunakan pada tanah salin adalah bakteri penambat N non simbiotik Azotobacter sp. dan Azospirillum sp. yang telah terbukti secara nyata mampu menambat $\mathrm{N}_{2}$ dari udara dan mensintesa zat pemacu tumbuh. Hasil penelitian Widawati (2015) menyimpulkan bahwa bakteri fungsional tanah salin kelompok PGPR, Azospirillum lipoferum strain 1103C dan Azotobacter crococcum strain 14103 yang diberikan secara tunggal maupun campuran berperan nyata sebesar $50 \%$ dalam partum- 
buhan dan produksi padi di tanah berpasir bersifat salin.

Aplikasi pupuk mikroba pada rhizosfer tanaman merupakan suatu hal yang kompleks, sehingga dalam pemanfaatannya perlu metoda aplikasi dan dosis yang tepat. Metoda aplikasi pupuk hayati penambat $\mathrm{N}$ dilakukan pada perlakuan benih, lahan persemaian dan gabungan (perlakuan benih + lahan persemaian), sedangkan dosis pupuk hayati dilakukan di pertanaman dalam jumlah tertentu per satuan luas (kg ha-1).

Hasil penelitian metoda aplikasi pupuk hayati Agrimeth $20 \mathrm{~g} \mathrm{~kg}^{-1}$ terhadap benih padi dengan dosis $300 \mathrm{~g} \mathrm{ha}^{-1}$ saat perlakuan benih (seed treatment) dapat meningkatkan produktivitas tanaman sebesar $20-50 \%$ dan menghemat biaya produksi (Jamil et. al., 2016). Hasil pengujian di lahan sawah Balai Penelitian Tanaman Padi Sukamandi pada tahun 2007 menunjukan bahwa dosis BioNutrient $200 \mathrm{~g}$ ha1 dapat menghemat kebutuhan pupuk urea dan SP-36 hingga 50\%, sedangkan dosis BioKom $320 \mathrm{~kg} \mathrm{ha}^{-1}$ dapat meningkatkan hasil $30-50 \%$, mengurangi kebutuhan pupuk urea dan SP-36 hingga 50\%, dan $\mathrm{KCl}$ 100\% (Saraswati et. al., 2007).

Aplikasi konsorsium bakteri Azotobacter sp. dan Azospirillum sp. toleran salin dalam bentuk formula pupuk hayati penambat $\mathrm{N}$ yang siap pakai dengan metoda aplikasi dan dosis yang tepat diharapkan mampu memenuhi kebutuhan unsur hara terutama $\mathrm{N}$ secara alami. Selain itu, aplikasi konsorsium kedua jenis bakteri tersebut diharapkan dapat mengurangi sensitifitas tanaman pada cekaman salinitas, dan meningkatkan kesehatan tanah. Pada akhirnya, aplikasi ini dapat meningkatkan produksi padi di tanah salin yang berkelanjutan dan ramah lingkungan.

Penelitian bertujuan untuk mendapatkan metoda aplikasi dan dosis pupuk hayati penambat $\mathrm{N}$ yang memberikan efek terbaik terhadap populasi bakteri, kadar $\mathrm{N}$, serapan $\mathrm{N}$, pertumbuhan, komponen hasil (jumlah malai per rumpun, jumlah gabah per malai, persentase gabah isi, dan bobot 1.000 butir) dan hasil panen tanaman padi pada tanah salin.

\section{METODE PENELITIAN}

Penelitian dilaksanakan di Kebun Percobaan BPP Cilamaya Wetan Kab. Karawang pada musim kemarau (MK) 2018 yakni selama 4 bulan, dari bulan Juni sampai September 2018. Ketinggian tempat 0,5 m dpl, suhu rata-rata siang hari $32^{\circ} \mathrm{C}$ dan malam hari $21^{\circ} \mathrm{C}$. Analisis kadar $\mathrm{N}$ dan serapan $\mathrm{N}$ tanaman di Laboratorium Kesuburan Tanah dan Nutrisi Tanaman Faperta UNPAD. Analisis awal populasi bakteri tanah dan pupuk hayati di Laboratorium Biologi Faperta UNPAD. Analisis populasi bakteri tanah pasca penelitian di Laboratorium Mikrobiologi BB Biogen Bogor.

Bahan yang digunakan dalam penelitian ini, yaitu benih padi varietas Inpari 35 , garam, telur, dan air secukupnya untuk seleksi benih, pupuk hayati penambat $\mathrm{N}$, konsorsium isolat Azotobacter sp. $\left(\mathrm{A}_{3}\right)$ dan Azospirillum sp. (Az-2), urea, NPK Phonska, tanah netral (ECe $<2$ dS.m1) dan salin sedang $\left(\mathrm{ECe}=4-8 \mathrm{dS} \cdot \mathrm{m}^{-1}\right)$, dan satu set bahan laboratorium untuk analisis kadar $\mathrm{N}$, serapan $\mathrm{N}$ tanaman dan pengukur populasi bakteri penambat $\mathrm{N}$.

Penelitian menggunakan Rancangan Acak Kelompok pola faktorial dalam 3 ulangan. Faktor pertama metoda aplikasi pupuk hayati (A) terdiri dari 4 taraf yaitu:

$$
\begin{aligned}
\mathrm{a}_{0}= & \text { kontrol (tanpa pupuk hayati) } \\
\mathrm{a}_{1}= & 300 \mathrm{~g} \mathrm{ha}^{-1} \text { perlakuan benih } \\
\mathrm{a}_{2}= & 400 \mathrm{~g} \mathrm{ha}^{-1} \text { lahan persemaian } \\
\mathrm{a}_{3}= & 700 \mathrm{~g} \mathrm{ha}^{-1}\left(300 \mathrm{~g} \mathrm{ha}^{-1}\right. \text { perlakuan benih } \\
& +400 \mathrm{~g} \mathrm{ha}^{-1} \text { lahan persemaian). }
\end{aligned}
$$

Faktor kedua dosis pupuk hayati (D) terdiri dari 4 taraf yaitu:

$$
\begin{aligned}
& \mathrm{d}_{0}=\text { kontrol (tanpa pupuk hayati) } \\
& \mathrm{d}_{1}=500 \mathrm{~g} \mathrm{ha}^{-1} \text { pupuk hayati } \\
& \mathrm{d}_{2}=1000 \mathrm{~g} \mathrm{ha}^{-1} \text { pupuk hayati } \\
& \mathrm{d}_{3}=1500 \mathrm{~g} \mathrm{ha}^{-1} \text { pupuk hayati }
\end{aligned}
$$

Benih dipilih yang bermutu baik dicirikan dengan mutu fisik bernas, daya berkecambah dan vigor tinggi. Seleksi benih dilakukan dengan merendam benih dalam larutan air garam $\left(20 \mathrm{~g} \mathrm{l}^{-1}\right.$ air; $\left.\mathrm{BJ}=1,125\right)$ dengan indikator telur. Benih yang terapung dan atau melayang dibuang dan benih yang tenggelam diambil, dibersihkan dan direndam selama 24 jam, kemu- 
dian benih diperam selama 48 jam sampai siap disemaikan. Benih disemaikan dengan cara ditabur di atas nampan berisi media tanah sawah netral $\left(\mathrm{ECe}<2 \mathrm{dS} \mathrm{m}^{-1}\right)$. Setelah bibit berumur 18 hari, dipilih bibit yang sehat untuk dipindahkan ke dalam pot berisi media tanah sawah salin sedang $\left(\mathrm{ECe}=4-8 \mathrm{dS} \mathrm{m}^{-1}\right)$.

Pot ukuran $8 \mathrm{~kg}$ di isi dengan $5 \mathrm{~kg}$ tanah salin sedang (ECe $=4-8 \mathrm{dS} \mathrm{m}^{-1}$ ) yang diambil dari lapisan olah (kedalaman $20 \mathrm{~cm}$ ) sawah pesisir pantai Desa Ciparage Kec. Cilamaya Kulon Kab. Karawang. Bibit umur 18 hari dipindahkan ke pot dengan cara ditanam dangkal dengan posisi akar memben-tuk hurup L pada kondisi tanah macak-macak dengan satu bibit per pot. Pot disusun acak sesuai dengan tata letak percobaan dengan 4 pot untuk tiap perlakuan dan diulang sebanyak 3 kali. Jarak tanam yang digunakan $20 \times 20 \mathrm{~cm}$. Bibit cadangan disiapkan disekitar pertanaman untuk keperluan penyulaman. Pot diisi air setinggi $2 \mathrm{~cm}$ dan dipertahankan hingga bulir matang susu, selanjutnya dilakukan pengeringan pada 1 minggu menjelang panen.

Aplikasi pupuk hayati penambat $\mathrm{N}$ dilakukan pagi hari sebelum jam 08.00 pagi dan tidak terjadi hujan. Cara aplikasi pupuk adalah sebagai berikut:

1. Perlakuan benih

Setelah benih direndam selama 24 jam dan diperam selama 48 jam, pupuk hayati sebanyak $300 \mathrm{~g} \mathrm{ha}^{-1}$ dicampurkan secara merata.

2. Persemaian

Aplikasi dilakukan dengan cara mencampurkan pupuk hayati dengan dosis $400 \mathrm{~g}$ ha $^{-1}$ dengan $20 \mathrm{~kg}$ kompos jerami dan selanjutnya disebarkan ke persemaian pada 1 hari sebelum sebar.

3. Pertanaman

Dosis pupuk hayati $500 \mathrm{~g} \mathrm{ha}^{-1}, 1.000 \mathrm{~g} \mathrm{ha}^{-1}$ dan $1.500 \mathrm{~g} \mathrm{ha}^{-1}$. Aplikasi dilakukan dengan mencampurkan pupuk hayati sesuai perlakuan dengan $500 \mathrm{~kg} \mathrm{ha}^{-1}$ kompos jerami dan selanjutnya disebarkan merata ke pertanaman sehari sebelum tanam.

Pemupukan kimia dilakukan sebanyak tiga kali dengan dosis per hektar sebagai berikut:
1. 7-10 HST: Urea $100 \mathrm{~kg}$ (N $46 \mathrm{~kg})+\mathrm{SP}-36$ $100 \mathrm{~kg}\left(\mathrm{P}_{2} \mathrm{O}_{5} 36 \mathrm{~kg}\right)$

2. 20-25 HST: Urea $50 \mathrm{~kg}(\mathrm{~N} 23 \mathrm{~kg})+\mathrm{KCl} 50$ $\mathrm{kg}\left(\mathrm{K}_{2} \mathrm{O} 30 \mathrm{~kg}\right)$

3. $35-40$ HST: Urea $50 \mathrm{~kg}(\mathrm{~N} 23 \mathrm{~kg})+\mathrm{KCl} 50$ $\mathrm{kg}\left(\mathrm{K}_{2} \mathrm{O} 30 \mathrm{~kg}\right)$.

Pengamatan yang dilakukan meliputi: populasi bakteri, kadar $\mathrm{N}$ dan serapan $\mathrm{N}$ tanaman; pertumbuhan Tanaman (tinggi tanaman dan jumlah anakan); komponen hasil (jumlah malai per rumpun, jumlah gabah per malai, persentase gabah isi, dan bobot 1.000 butir); dan Grain Straw Ratio (GSR).

\section{HASIL DAN PEMBAHASAN}

\subsection{Populasi bakteri, kadar $\mathbf{N}$ dan serapan $\mathbf{N}$ tanaman}

Hasil analisis statistik menunjukan bahwa tidak terjadi interaksi antara perlakuan metoda aplikasi dan dosis pupuk hayati terhadap populasi bakteri, kadar $\mathrm{N}$ dan serapan $\mathrm{N}$ tanaman (Tabel 1). Perlakuan metoda aplikasi pupuk hanyati $700 \mathrm{~g} \mathrm{ha}^{-1}$ (300 $\mathrm{g} \mathrm{ha}^{-1}$ perlakuan benih $+400 \mathrm{~g} \mathrm{ha}^{-1}$ lahan persemaian) nyata berpengaruh terhadap meningkatkan populasi bakteri (Azotobacter sp. dan Azospirillum sp.) dan serapan $\mathrm{N}$ tanaman, tetapi tidak dapat meningkatkan kadar $\mathrm{N}$ tanaman. Keadaan tersebut diduga karena kadar $\mathrm{N}$ tanaman pada semua perlakuan metoda aplikasi pupuk hayati sudah berada di atas nilai batas defisiensi $\mathrm{N}<$ $2,0 \%$ dan pada tingkat kecukupan $\mathrm{N}=2,2$ 3,6\% (Dobermann dan Fairhurst, 2000).

Dosis pupuk hayati $1000 \mathrm{~g} \mathrm{ha}^{-1}$ dan $1500 \mathrm{~g}$ ha $^{-1}$ nyata dapat meningkatkan populasi bakteri, kadar $\mathrm{N}$ dan serapan $\mathrm{N}$ tanaman. Dosis pupuk hayati $1.500 \mathrm{~g} \mathrm{ha}^{-1}$ nyata dapat meningkatkan populasi bakteri sebesar 3 kali dari populasi kontrol. Data menunjukan bahwa batas minimal dosis pupuk hayati yang dapat meningkatkan populasi bakteri, kadar $\mathrm{N}$ dan serapan $\mathrm{N}$ tanaman ada pada dosis $1.000 \mathrm{~g} \mathrm{ha}^{-1}$. Fenomena ini memberikan pemahaman bahwa metoda aplikasi pupuk hayati di awal pertumbuhan tanaman dengan dosis yang cukup, mutlak diperlukan untuk meningkatkan populasi bakteri di rhizosfer tanaman. 
Tabel 1 Efek metoda aplikasi dan dosis pupuk hayati terhadap populasi bakteri, kadar $\mathrm{N}$ dan serapan N tanaman padi pada tanah salin, Cilamaya Wetan MK 2018

\begin{tabular}{|c|c|c|c|c|}
\hline $\begin{array}{c}\text { Perlakuan pupuk } \\
\text { hayati }\end{array}$ & Azotobacter sp. & Azospirillum sp. & Kadar N & Serapan N \\
\hline$\left(\right.$ g.ha $\left.^{-1}\right)$ & $\left(10^{7}\right.$ CFU.g-1) & $\left(10^{8}\right.$ CFU.g-1) $\left.^{-1}\right)$ & $(\%)$ & (g/tanaman) \\
\hline \multicolumn{5}{|l|}{ Metoda aplikasi (A) } \\
\hline $\mathrm{a}_{0}=$ control & $1,49 a$ & $1,10 \mathrm{a}$ & $2,69 \mathrm{a}$ & $3,87 \mathrm{a}$ \\
\hline $\mathrm{a}_{1}=300^{*}$ & $1,85 \mathrm{ab}$ & $1,44 \mathrm{a}$ & $2,71 \mathrm{a}$ & $3,90 \mathrm{a}$ \\
\hline $\mathrm{a}_{2}=400 * *$ & $2,79 \mathrm{bc}$ & $2,19 \mathrm{~b}$ & $2,85 \mathrm{a}$ & $4,22 \mathrm{ab}$ \\
\hline $\mathrm{a}_{3}=700^{* * *}$ & $3,65 c$ & $2,23 \mathrm{~b}$ & $2,89 \mathrm{a}$ & $4,48 \mathrm{~b}$ \\
\hline \multicolumn{5}{|l|}{ Dosis (D) } \\
\hline $\mathrm{d}_{0}=$ kontrol & $1,41 \mathrm{a}$ & $0,93 \mathrm{a}$ & $2,52 \mathrm{a}$ & $3,22 \mathrm{a}$ \\
\hline $\mathrm{d}_{1}=500$ & $1,57 \mathrm{ab}$ & $1,28 \mathrm{~b}$ & $2,74 \mathrm{~b}$ & $3,84 \mathrm{~b}$ \\
\hline $\mathrm{d}_{2}=1000$ & $2,53 \mathrm{~b}$ & $1,93 \mathrm{c}$ & $2,84 \mathrm{bc}$ & $4,38 \mathrm{c}$ \\
\hline $\mathrm{d}_{3}=1500$ & $4,28 \mathrm{c}$ & $2,83 \mathrm{~d}$ & $3,03 \mathrm{c}$ & $5,03 \mathrm{~d}$ \\
\hline $\mathrm{Kk}(\%)$ & 55,22 & 32,90 & 9,09 & 15,46 \\
\hline
\end{tabular}

Metoda aplikasi pupuk hayati di awal pertumbuhan tanaman dengan menempatkan (inokulasi) mikroba terpilih pada biji (benih) atau perakaran (bibit/tanaman) dalam jumlah yang cukup. Kondisi ini memberi kesempatan lebih besar kepada inokulan pupuk hayati untuk melakukan kolonisasi awal sehingga inokulan dapat berkembang dengan pesat, meningkatkan daya saing terhadap mikroba pribumi (endogenus), membantu penyediaan hara, dan meningkatkan pertumbuhan tanaman (Simanungkalit et al., 2001).

\subsection{Pertumbuhan Tanaman}

Hasil analisis statistik menunjukan bahwa tidak terjadi interaksi antara perlakuan metoda aplikasi dan dosis pupuk hayati terhadap tinggi tanaman (Tabel 2). Semua metoda aplikasi pupuk hayati baik perlakuan benih maupun di persemaian tidak berpengaruh nyata terhadap tinggi tanaman pada saat panen. Namun, sebaliknya semua perlakuan dosis pupuk hayati di pertanaman nyata meningkatkan tinggi tanaman pada saat panen.

Tabel 2 Efek metoda aplikasi dan dosis pupuk hayati terhadap pertumbuhan tinggi tanaman padi pada tanah salin, Cilamaya Wetan MK 2018

\begin{tabular}{ccccc}
\hline $\begin{array}{c}\text { Perlakuan pupuk hayati } \\
\text { (g.ha- }{ }^{-1} \text { ) }\end{array}$ & \multicolumn{4}{c}{ Tinggi tanaman (cm) } \\
\cline { 2 - 5 } & $30 \mathrm{HST}$ & $40 \mathrm{HST}$ & $50 \mathrm{HST}$ & Panen \\
\hline Metoda aplikasi (A) & $53,98 \mathrm{a}$ & $67,68 \mathrm{a}$ & $82,82 \mathrm{a}$ & $93,13 \mathrm{a}$ \\
$\mathrm{a}_{0}=$ control & $55,31 \mathrm{ab}$ & $67,89 \mathrm{ab}$ & $83,64 \mathrm{ab}$ & $93,19 \mathrm{a}$ \\
$\mathrm{a}_{1}=300^{*}$ & $55,74 \mathrm{~b}$ & $68,78 \mathrm{~b}$ & $83,85 \mathrm{~b}$ & $93,77 \mathrm{a}$ \\
$\mathrm{a}_{2}=400^{* *}$ & $57,82 \mathrm{c}$ & $68,79 \mathrm{~b}$ & $84,95 \mathrm{c}$ & $94,30 \mathrm{a}$ \\
$\mathrm{a}_{3}=700^{* * *}$ & & & & \\
Dosis (D) & $51,88 \mathrm{a}$ & $64,38 \mathrm{a}$ & $80,20 \mathrm{a}$ & $88,74 \mathrm{a}$ \\
$\mathrm{d}_{0}=$ kontrol & $54,42 \mathrm{~b}$ & $67,04 \mathrm{~b}$ & $82,77 \mathrm{~b}$ & $92,48 \mathrm{~b}$ \\
$\mathrm{~d}_{1}=500$ & $56,79 \mathrm{c}$ & $69,37 \mathrm{c}$ & $84,90 \mathrm{c}$ & $95,00 \mathrm{c}$ \\
$\mathrm{d}_{2}=1000$ & $59,77 \mathrm{~d}$ & $72,35 \mathrm{~d}$ & $87,38 \mathrm{~d}$ & $98,17 \mathrm{~d}$ \\
\hline $\mathrm{d}_{3}=1500$ & 28,63 & 16,49 & 13,65 & 18,00 \\
\hline Kk $(\%)$ &
\end{tabular}

Keterangan: Angka yang ditandai dengan huruf sama tidak berbeda nyata pada uji DMRT taraf 5\%; *perlakuan benih; *lahan persemaian; *** $300 \mathrm{~g} \mathrm{ha}^{-1}$ perlakuan benih $+400 \mathrm{~g} \mathrm{ha}^{-1}$ lahan persemaian. 
Hasil analisis statistik menunjukkan bahwa tidak terjadi interaksi antara perlakuan metoda aplikasi dan dosis pupuk hayati terhadap jumlah anakan (Tabel 3). Perlakuan metoda aplikasi pupuk hanyati $700 \mathrm{~g} \mathrm{ha}^{-1}(300$ $\mathrm{g} \mathrm{ha}^{-1}$ perlakuan benih $+400 \mathrm{~g}^{\text {ha-1 }}{ }^{-1}$ lahan persemaian) dan semua perlakuan dosis pupuk hayati di pertanaman nyata meningkat-kan jumlah anakan pada saat panen. Kadar N pada semua perlakuan dosis pupuk hayati di pertanaman nyata lebih tinggi dibandingkan kontrol (Tabel 1). Fenomena ini menunjukkan bahwa tinggi tanaman dan pembentukan anakan ditentukan oleh kadar N. Padi memerlukan sejumlah $\mathrm{N}$ untuk pertumbuhan tinggi dan pembentukan anakan (Ishuzaka, 1978). Tanaman yang cukup $\mathrm{N}$ akan tumbuh lebih tinggi, anakan lebih banyak, dan daun lebih hijau (Balai Penelitian Tanaman Padi, 2004).

Tabel 3 Efek metoda aplikasi dan dosis pupuk hayati terhadap pertumbuhan anakan tanaman padi pada tanah salin, Cilamaya Wetan MK 2018

\begin{tabular}{ccccc}
\hline $\begin{array}{c}\text { Perlakuan Pupuk hayati } \\
\text { (g.ha- } \text { - }^{\text {) }}\end{array}$ & \multicolumn{4}{c}{ Anakan (anakan/rumpun) } \\
\cline { 2 - 5 } & $30 \mathrm{HST}$ & $40 \mathrm{HST}$ & $50 \mathrm{HST}$ & Panen \\
\hline $\begin{array}{c}\text { Metoda aplikasi (A) } \\
\mathrm{a}_{0}=\text { control }\end{array}$ & $19,08 \mathrm{a}$ & $24,02 \mathrm{a}$ & $26,44 \mathrm{a}$ & $20,56 \mathrm{a}$ \\
$\mathrm{a}_{1}=300^{*}$ & $19,75 \mathrm{ab}$ & $25,04 \mathrm{ab}$ & $28,10 \mathrm{~b}$ & $21,44 \mathrm{ab}$ \\
$\mathrm{a}_{2}=400^{* *}$ & $20,73 \mathrm{ab}$ & $25,71 \mathrm{ab}$ & $28,21 \mathrm{~b}$ & $21,44 \mathrm{ab}$ \\
$\mathrm{a}_{3}=700^{* * *}$ & $21,27 \mathrm{~b}$ & $26,44 \mathrm{~b}$ & $28,30 \mathrm{~b}$ & $22,63 \mathrm{~b}$ \\
Dosis (D) & & & & \\
$\mathrm{d}_{0}=$ kontrol & $15,94 \mathrm{a}$ & $19,54 \mathrm{a}$ & $22,23 \mathrm{a}$ & $17,81 \mathrm{a}$ \\
$\mathrm{d}_{1}=500$ & $18,10 \mathrm{~b}$ & $23,85 \mathrm{~b}$ & $26,17 \mathrm{~b}$ & $20,40 \mathrm{~b}$ \\
$\mathrm{~d}_{2}=1000$ & $21,63 \mathrm{c}$ & $26,60 \mathrm{c}$ & $29,02 \mathrm{c}$ & $22,35 \mathrm{c}$ \\
$\mathrm{d}_{3}=1500$ & $25,17 \mathrm{~d}$ & $31,21 \mathrm{~d}$ & $33,63 \mathrm{~d}$ & $25,50 \mathrm{~d}$ \\
\hline Kk (\%) & 10,25 & 8,52 & 7,00 & 7,07 \\
\hline
\end{tabular}

Keterangan: Angka yang ditandai dengan huruf sama tidak berbeda nyata pada uji DMRT taraf 5\%; *perlakuan benih; *lahan persemaian; ${ }^{* * *} 300$ g.ha $^{-1}$ perlakuan benih +400 g.ha ${ }^{-1}$ lahan persemaian.

Ketersediaan $\mathrm{N}$ yang cukup menyebabkan tanaman mampu membentuk anakan yang lebih banyak selama pertumbuhannya sampai tercapai jumlah anakan maksimum sehingga jumlah anakan yang tersisa pada saat panen lebih banyak. Sebaliknya kekurangan N menyebabkan pembelahan sel terhambat dan dapat menyusutkan pertumbuhan (Poerwowidodo, 1993), sehingga tinggi tanaman lebih rendah dengan jumlah anakan lebih sedikit.

\subsection{Komponen Hasil dan Hasil Panen}

Komponen hasil yang diamati adalah jumlah malai per rumpun, jumlah gabah per malai, persentase gabah isi, dan bobot 1.000 butir. Hasil analisis statistik menunjukan bahwa tidak terjadi interaksi antara perlakuan metoda aplikasi dan dosis pupuk hayati terhadap jumlah malai per rumpun, jumlah gabah per malai dan persentase gabah isi (Tabel 4). Metoda aplikasi pupuk hayati $700 \mathrm{~g}$ ha $^{-1}$ nyata meningkatkan jumlah malai per rumpun dan persentase gabah isi.

Dosis pupuk hayati $\left(1.000 \mathrm{~g} \mathrm{ha}^{-1}\right.$ dan 1.500 g ha-1) nyata meningkatkan jumlah malai per rumpun, jumlah gabah per malai dan persentase gabah isi. Jumlah malai per rumpun ditentukan oleh jumlah anakan yang terbentuk pada fase pertumbuhan. Anakan mulai terbentuk sejak umur 10 hari dan mencapai maksimum pada 50-60 hari setelah tanam. Setelah itu, anakan akan berkurang dikarenakan anakan yang lemah mati. Anakan yang mati pada umumnya disebabkan karena anakan tersebut ternaungi oleh sesamanya, atau kekurangan unsur hara, terutama nitrogen (Vergara, 1990). Nitrogen berperan meningkatkan jumlah gabah per malai (Fairhurst et. al., 2007). 
Tabel 4 Efek metoda aplikasi dan dosis pupuk hayati terhadap jumlah malai per rumpun, jumlah gabah per malai dan persentase gabah isi tanaman padi pada tanah salin, Cilamaya Wetan MK 2018

\begin{tabular}{|c|c|c|c|}
\hline $\begin{array}{c}\text { Perlakuan pupuk } \\
\text { hayati } \\
\text { (g ha-1) }^{-1}\end{array}$ & $\begin{array}{c}\text { Malai } \\
\text { gram per rumpun }\end{array}$ & $\begin{array}{c}\text { Gabah } \\
\text { gram per malai }\end{array}$ & $\begin{array}{c}\text { Gabah isi } \\
(\%)\end{array}$ \\
\hline \multicolumn{4}{|l|}{ Metoda aplikasi (A) } \\
\hline $\mathrm{a}_{0}=$ control & $15,64 \mathrm{a}$ & $95,20 \mathrm{a}$ & $59,90 \mathrm{a}$ \\
\hline$a_{1}=300^{*}$ & $16,33 \mathrm{ab}$ & $96,45 \mathrm{a}$ & $61,73 a b$ \\
\hline $\mathrm{a}_{2}=400^{* *}$ & $16,92 \mathrm{ab}$ & $98,85 \mathrm{a}$ & $62,34 \mathrm{ab}$ \\
\hline $\mathrm{a}_{3}=700^{* * *}$ & $17,28 \mathrm{c}$ & $99,71 \mathrm{a}$ & $63,54 \mathrm{~b}$ \\
\hline \multicolumn{4}{|l|}{ Dosis (D) } \\
\hline $\mathrm{d}_{0}=$ kontrol & $14,33 \mathrm{a}$ & $80,01 \mathrm{a}$ & $55,46 \mathrm{a}$ \\
\hline $\mathrm{d}_{1}=500$ & $15,50 \mathrm{a}$ & $93,80 \mathrm{~b}$ & $60,10 \mathrm{~b}$ \\
\hline $\mathrm{d}_{2}=1.000$ & $16,97 \mathrm{~b}$ & $102,41 \mathrm{c}$ & $64,23 \mathrm{c}$ \\
\hline $\mathrm{d}_{3}=1.500$ & $19,36 \mathrm{c}$ & $113,99 \mathrm{~d}$ & $67,72 \mathrm{~d}$ \\
\hline $\mathrm{Kk}(\%)$ & 9,82 & 8,99 & 6,31 \\
\hline
\end{tabular}

Keterangan: Angka yang ditandai dengan huruf sama tidak berbeda nyata pada uji DMRT taraf 5\%; *perlakuan benih; *lahan persemaian; ${ }^{* * *} 300 \mathrm{~g} \mathrm{ha}^{-1}$ perlakuan benih $+400 \mathrm{~g} \mathrm{ha}^{-1}$ lahan persemaian.

Persentase gabah isi yang rendah $(59,90$ $67,72 \%)$ menunjukan bahwa persentase gabah hampa yang tinggi, diduga karena pengaruh salinitas yang menyebabkan berkurangnya kemampuan tanaman untuk menyerap air, $\mathrm{CO}_{2}$, dan mineral hara terutama $\mathrm{K}^{+}$akibat besarnya nisbah $\mathrm{Na}: \mathrm{K}$ (Joseph \&
Mohanan, 2013). Air dan $\mathrm{CO}_{2}$ adalah bahan dasar fotosintesis, $\mathrm{K}$ berfungsi memindahkan produk fotosintesis ke gabah (Fairhurst et. al., 2007) dan kekurangan air pada fase berbunga meningkatkan persentase gabah hampa karena berkurangnya fertilitas spikelet (Arzie et. al., 2015).

Tabel 5 Efek Metoda aplikasi dan dosis pupuk hayati terhadap bobot 1000 butir, hasil panen dan GSR tanaman padi pada tanah salin, Cilamaya Wetan MK 2018

\begin{tabular}{ccccc}
\hline $\begin{array}{c}\text { Perlakuan pupuk } \\
\text { hayati } \\
\text { (g.ha-1) }\end{array}$ & $\begin{array}{c}\text { Bobot 1000 butir } \\
\text { gabah isi } \\
\text { (gram) }\end{array}$ & $\begin{array}{c}\text { Hasil panen } \\
\text { (ton.ha-1 GKG) }\end{array}$ & $\begin{array}{c}\text { Kenaikan hasil } \\
\text { panen } \\
(\%)\end{array}$ & GSR \\
\hline $\begin{array}{c}\text { Metoda aplikasi }(\mathrm{A}) \\
\mathrm{a}_{0}=\text { kontrol }\end{array}$ & $25,06 \mathrm{a}$ & $4,74 \mathrm{a}$ & - & $1,04 \mathrm{a}$ \\
$\mathrm{a}_{1}=300^{*}$ & $25,87 \mathrm{~b}$ & $4,80 \mathrm{a}$ & 1,27 & $0,97 \mathrm{ab}$ \\
$\mathrm{a}_{2}=400^{* *}$ & $26,00 \mathrm{~b}$ & $4,83 \mathrm{a}$ & 1,90 & $0,91 \mathrm{ab}$ \\
$\mathrm{a}_{3}=700^{* * *}$ & $26,28 \mathrm{~b}$ & $5,03 \mathrm{a}$ & 6,12 & $0,86 \mathrm{~b}$ \\
Dosis (D) & & & & \\
$\mathrm{d}_{0}=$ kontrol & $24,53 \mathrm{a}$ & $4,31 \mathrm{a}$ & - & $1,17 \mathrm{a}$ \\
$\mathrm{d}_{1}=500$ & $25,58 \mathrm{~b}$ & $4,56 \mathrm{ab}$ & 5,80 & $0,96 \mathrm{~b}$ \\
$\mathrm{~d}_{2}=1000$ & $26,21 \mathrm{c}$ & $4,94 \mathrm{~b}$ & 14,62 & $0,86 \mathrm{bc}$ \\
$\mathrm{d}_{3}=1500$ & $26,89 \mathrm{~d}$ & $5,59 \mathrm{c}$ & 29,70 & $0,79 \mathrm{c}$ \\
\hline Kk $(\%)$ & 26,85 & 9,36 & - & 17,06 \\
\hline
\end{tabular}

Keterangan: Angka yang ditandai dengan huruf sama tidak berbeda nyata pada uji DMRT taraf 5\%; *perlakuan benih; *lahan persemaian; ${ }^{* *} 300 \mathrm{~g} \mathrm{ha}^{-1}$ perlakuan benih $+400 \mathrm{~g} \mathrm{ha}^{-1}$ lahan persemaian.

Hasil analisis statistik menunjukan bahwa tidak terjadi interaksi antara perlakuan metoda aplikasi dan dosis pupuk hayati terhadap bobot 1000 butir gabah isi, hasil panen dan nilai GSR. (Tabel 5). Metoda aplikasi pupuk hayati $700 \mathrm{~g}$ ha $^{-1}$ nyata meningkatkan bobot 1000 butir gabah isi dan menurunkan nilai GSR. Dosis pupuk hayati $\left(1.000 \mathrm{~g} \mathrm{ha}^{-1} \mathrm{dan}\right.$ 
$1.500 \mathrm{~g} \mathrm{ha}^{-1}$ ) nyata meningkatkan bobot 1.000 butir gabah isi dan hasil panen.

Hasil panen ditentukan oleh komponen hasil dan oleh setiap tingkat pertumbuhan yang dipengaruhi faktor lingkungan. Jumlah anakan yang terbentuk, yang menentukan jumlah malai, adalah faktor yang paling penting untuk mendapatkan hasil gabah yang tinggi (Vergara, 1990). Jumlah malai per rumpun yang sedikit tidak dapat disubtitusi oleh kenaikan jumlah gabah per malai, persentase gabah isi, dan bobot 1000 butir gabah isi, karena ketiga komponen ini tidak bervariasi banyak. Dosis pupuk hayati $1500 \mathrm{~g} \mathrm{ha}^{-1} \mathrm{mampu}$ memberikan kadar $\mathrm{N}$ dan serapan $\mathrm{N}$ tanaman tertinggi (Tabel 1) untuk membentuk jumlah anakan dan jumlah malai yang banyak (Tabel 3 dan 4), sehingga memberikan hasil panen tertinggi yaitu 5,59 $\mathrm{t} \mathrm{ha}^{-1}$ (Gambar 1) dengan peningkatan hasil panen sebesar 29,70\% (Tabel 5).

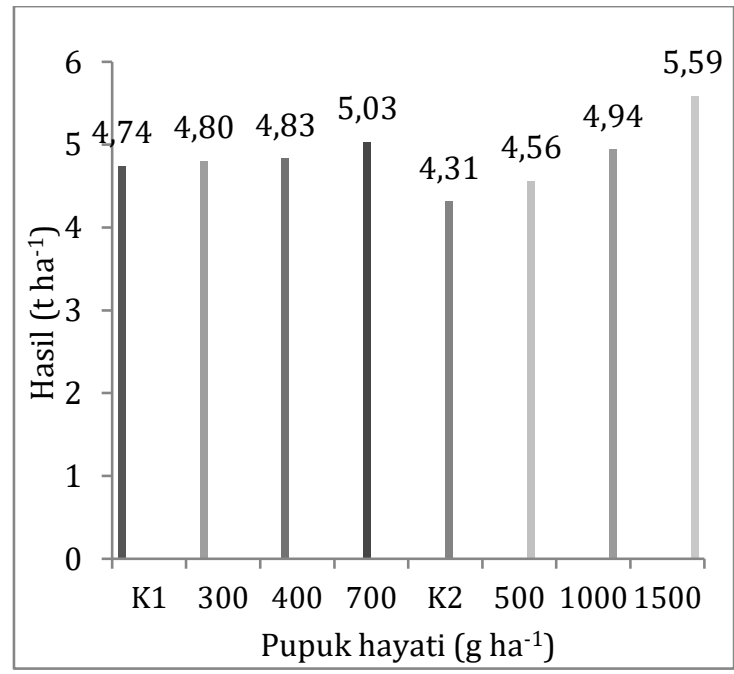

Gambar 1 Efek metoda aplikasi dan dosis pupuk hayati terhadap hasil panen

Nilai GSR lebih ditentukan oleh banyaknya $\mathrm{N}$ yang diserap tanaman padi dari pada unsur $\mathrm{K}$. Hara $\mathrm{N}$ yang cukup dan $\mathrm{K}$ kurang akan menurunkan nilai GSR karena $\mathrm{N}$ lebih banyak digunakan tanaman untuk pertumbuhan vegetatif. Kondisi ini sesuai dengan hasil penelitian sebelumnya, bahwa $\mathrm{N}$ yang cukup menghasilkan bobot jerami lebih tinggi dan kekurangan $\mathrm{K}$ menurunkan hasil panen (Doberman and Fairhust, 2000).

\section{KESIMPULAN}

Berdasarkan hasil penelitian dapat diambil kesimpulan sebagai berikut:

1. Tidak terjadi interaksi antara perlakuan metoda aplikasi dan dosis pupuk hayati penambat $\mathrm{N}$ terhadap serapan $\mathrm{N}$, pertumbuhan dan hasil tanaman padi pada tanah salin.

2. Perlakuan metoda aplikasi pupuk hanyati $700 \mathrm{~g} \mathrm{ha}^{-1}$ (300 $\mathrm{g} \mathrm{ha}^{-1}$ perlakuan benih + $400 \mathrm{~g} \mathrm{ha}^{-1}$ lahan persemaian) nyata meningkatkan populasi bakteri (Azotobacter sp. dan Azospirillum sp.), serapan N tanaman, jumlah anakan pada saat panen, jumlah malai per rumpun, persentase gabah isi, bobot 1.000 butir gabah isi dan menurunkan nilai GSR.

3. Dosis pupuk hayati $1000 \mathrm{~g} \mathrm{ha}^{-1}$ dan 1.500 $\mathrm{g}$ ha-1 nyata dapat meningkatkan populasi bakteri (Azotobacter sp. dan Azospirillum sp.), tinggi tanaman, jumlah anakan, jumlah malai per rumpun, jumlah gabah per malai, persentase gabah isi, bobot 1000 butir gabah isi dan menurunkan nilai GSR.

4. Perlakuan dosis pupuk hayati $1.500 \mathrm{~g} \mathrm{ha}^{-1}$ mampu meningkatan hasil panen sebesar $29,70 \%$.

\section{UCAPAN TERIMA KASIH}

Ucapan terimakasih atas bimbingan, arahan dan dorongan motivasinya kepada yang terhormat:

1. Ir. Briljan Sudjana, MS., MBA (Almarhum) sebagai pembimbing lapangan;

2. Seluruh civitas akademik Universitas Padjadjaran, dosen, staf administrasi dan teman-teman mahasiswa Program Pascasarjana Fakultas Pertanian angkatan 2016 khususnya grup Karawang.

3. Semua pihak yang telah membantu selama penulisan artikel ilmiah ini.

\section{DAFTAR PUSTAKA}

Arzie, D., A. Qadir, dan F. C. Suwarno. 2015. Pengujian Toleransi Genotipe Padi (Oryza sativa L) terhadap Salinitas 
pada Stadia Perkecambahan. Bul. Agrohorti 3 (3): 377 - 386.

Balai Penelitian Tanaman Padi, 2004. Inovasi Teknologi untuk Peningkatan Produksi Padi dan Kesejahteraan Petani. Pusat Penelitian dan Pengembangan Tanaman Pangan, Badan Litbang Pertanian Deptan

BPS, 2017. Kajian Konsumsi Bahan Pokok Tahun 2017. Badan Pusat Statistik, Jakarta-Indonesia. https://www.bps.go.id/publication/2 019/06/25/bbf8ec1716fb458368799 6c3/kajian-konsumsi-bahan-pokoktahun-2017.html.

Doberman A and Fairhust T. 2000. Rice Nutrient Disorders and Nutrient Management, Potash and Phosphate Institute of Canada and International Rice Research Institute. Philippines (PH): Oxford Geographic Printers Pte Ltd. p:139-144.

Erfandi, D. dan Juarsah, I. 2013. Reklamasi lahan untuk mengatasi salinitas sawah. Dalam Buku Konservasi Tanah Menghadapi Perubahan Iklim Balai Penelitian Tanah. Balai Penelitian dan Pengembangan Pertanian. Hal: 135158.

Fairhust, T., C. Witt, R. J. Buresh, A. Doberman. 2007. Padi: Panduan Praktis Pengelolaan Hara. A. Widjono, penterjemah. Badan Litbang Pertanian Jakarta.

Ishuzaka, Y. 1978. Nutrient Deficiencies of Crop, Rev. Ed. ASPAC Food Fert. Tech. Cent., Taipei, Taiwan.

Jamil, A., S. Abdulrachman, P. Sasmita, Z. Zaini, Wiratno, R. Rachmat, R. Saraswati, L. Retno Widowati, E. Pratiwi, Satoto, Rahmini, D. D. Handoko, L. M. Zarwazi, M.Y. Samaullah, A. Maolana Yusup, dan A. D. Subagio. 2016. Petunjuk Teknis Budidaya Padi Jajar Legowo Super. Badan Penelitian dan Pengembangan Pertanian, Kementerian Pertanian.

Joseph, E. A. and Mohanan, K. V. 2013. A study on the effect of salinity stress on the growth and yield of some native rice cultivars of kerala state of india.
Agriculture. Forestry and Fisheries. 2 (3): 141-150.

Poerwowidodo, M. 1993. Telaah Kesuburan Tanah. Angkasa Bandung.

Saraswati, R., dan Husen, E. 2007. Prospek Penggunaan Pupuk Hayati pada Sawah Bukaan Baru. Balai Besar Penelitian dan Pengembangan Sumberdaya Lahan Pertanian. Bogor.

Simanungkalit, R. D. M. 2001. Aplikasi Pupuk Hayati dan Pupuk Kimia: Suatu Pendekatan Terpadu. Buletin AgroBio 4(2):56-61

Wahyunto. 2009. Lahan sawah di Indonesia sebagai pendukung ketahanan pangan nasional. Informatika Pertanian 18 (2):133-152.

Waters, J. K., B. L. Hughes II, L. C. Purecell, K. O. Gerhardt, T. P. Mowhinney, and D. W. Emerich. 1998. Alanine, not ammonia, is excreted from $\mathrm{N} 2$-fixing soybean nodule bacteroids. Proc. Natl. Acad. Sci. Vol. 95: 12038-42.

Widawati, S. 2015. Peran bakteri fungsional tahan salin (PGPR) pada pertumbuhan padi di tanah berpasir salin. Proseding Seminar Nasional Masyarakat Biodiversity Indonesia 1(8): 1856 1860.

Vergara, B. S. 1990. Bercocok Tanam Padi. Terjemahan Proyek Penyuluhan Pertanian Tanaman Pangan. Proyek Prasarana Fisik Bappenas. 